\title{
HUBUNGAN KUALITAS LAYANAN PERPUSTAKAAN DENGAN CITRA BAPUSIPDA PROVINSI JAWA BARAT
}

\author{
Asep Gunawan*, Encang Saepudin*, Yunus Winoto*
}

Pengutipan: Gunawan, A., Saepudin, E., dan Winoto, Y. (2015). Hubungan kualitas layanan perpustakaan dengan citra BAPUSIPDA Provinsi Jawa Barat. Khizanah al-Hikmah : Jurnal Ilmu Perpustakaan, Informasi, dan Kearsipan, 5(1), 84-93.

DOI: http:/ /dx.doi.org/10.24252/kah.v5i1a7

*Program Studi Ilmu Perpustakaan Universitas Padjadjaran, Bandung

asep.gunawan9393@gmail.com, encang@unpad.ac.id,yunuswinoto@unpad.ac.id

\begin{abstract}
ABSTRAK
Penelitian ini bertujuan untuk mengetahui sejauh mana hubungan kualitas layanan perpustakaan dengan citra perpustakaan BAPUSIPDA Provinsi Jawa Barat. Metode penelitian ini menggunakan pendekatan kuantitatif dengan analisis survei eksplanatif. Teknik pengumpulan data dalam penelitian ini menggunakan kuesioner, wawancara, observasi, dan studi pustaka. Adapun populasi dalam penelitian ini adalah anggota perpustakaan BAPUSIPDA yang aktif memanfaatkan perpustakaan pada bulan April tahun 2016 yaitu sebanyak 664 orang, sedangkan sampel dalam penelitian ini sebanyak 87 orang. Teknik pengambilan sampel yang digunakan dalam penelitian ini yaitu teknik simple random sampling. Hasil dari penelitian ini menujukkan bahwa terdapat hubungan positif yang signifikan antara kualitas layanan perpustakaan dengan citra perpustakaan BAPUSIPDA Provinsi Jawa Barat, dengan koefisien korelasi (0.721), artinya hubungan kualitas layanan perpustakaan dengan citra perpustakaan BAPUSIPDA Provinsi Jawa Barat pada taraf yang kuat.
\end{abstract}

Kata kunci: Kualitas layanan perpustakaan, citra perpustakaan, perpustakaan umum

\section{ABSTRACT}

The aim of the research is to know the correlation between the service quality and the image BAPUSIPDA Library West Java Province. This research uses a quantitative approach with survey explanative analysis. Data collection techniques used in this research are questionnaire, interview, observation, and literature study. The population in this research are 664 active members of BAPUSIPDA who use the library in April 2016, while the sample in this research as many as 87 people. The sampling technique used in this research is simple random sampling technique. The results of this research indicate that there is a significant positive correlation between the quality of library services and the image of the BAPUSIPDA library West Java Province, with correlation coefficients (0721), it means that the correlation between the service quality and the image BAPUSIPDA Library West Java Province is on a strong level.

Key words: Quality of library service, library image, public library 


\section{PENDAHULUAN}

Peranan perpustakaan pada abad sekarang ini tidak lagi terbatas pada pengolahan buku, melainkan mencakup koleksi lain yang bukan buku, seperti majalah, surat kabar, tape, film, microfilm, dan dalam bentuk digital seperti elektronik jurnal (e-journal), buku elektronik (e-Book) dan sebagainya. Kemajuan ilmu pengetahuan dan teknologi telah membawa perubahan besar dalam kehidupan umat manusia. Berbagai kemajuan tersebut juga memberikan dampak pada dunia perpustakaan sebagai sumber informasi yang menyimpan informasi dalam berbagai bentuk dan jenis, menjadi salah satu sarana yang dapat dimanfaatkan oleh seluruh anggota masyarakat untuk pemenuhan kebutuhan tersebut, seperti untuk penelitian, belajar, mengisi waktu luang, dan sebagainya. Oleh karena itu, saat ini perpustakaan menjadi bagian paling penting dalam pengelolaan informasi dan dituntut untuk memberikan pelayanan jasa yang sebesar-besarnya kepada para pemakai sebagai sumber informasi.

Kondisi kebutuhan informasi ilmiah dewasa ini menuntut perpustakaan harus berupaya untuk memahami-kebutuhan, keinginan, dan permintaan informasi pemustaka. Sehingga perpustakaan harus mampu mengadakan dan menyediakan informasi yang relevan dengan kebutuhan pemustaka tersebut. Dalam dunia bisnis, upaya ini dikenal sebagai upaya mempertahankan citra perusahaan dengan cara memberikan layanan yang baik kepada pelanggan. Pelayanan yang baik ini diharapkan akan membangun citra positif yang pada akhirnya akan memberikan keuntungan jangka panjang bagi perusahaan. Begitu pula perpustakaan, pada masa sekarang ini perpustakaan harus berusaha untuk membangun loyalitas pemustaka sebagai pelanggan perpustakaan.

Perkembangan suatu perpustakaan dapat dilihat dari pelayanannya, karena keberhasilan pelayanan merupakan tujuan akhir yang ingin dicapai oleh perpustakaan. Dengan demikian perpustakaan harus menyediakan fasilitas sebaik mungkin seperti koleksi yang sesuai dengan kebutuhan pemakai, pengguna perpustakaan merasa puas dengan pelayanan yang diberikan oleh perpustakaan. Hal ini sejalan dengan pendapat Sulistyo-Basuki yang menyatakan "kegiatan jasa layanan sering kali dianggap ujung tombak dari suatu perpustakaan karena bagian inilah yang pertama kali berhubungan dengan pengguna atau pemakai serta paling sering digunakan pengguna, karena itu unjuk kerja staf dapat berpengaruh terhadap citra perpustakaan" (SulistyoBasuki, 2010, 257).

Kualitas layanan perpustakaan BAPUSIPDA dapat dilihat dari dua sisi, yaitu: pertama, hal-hal yang dapat mendukung peningkatan kualitas layanan perpustakaan adalah SDM (sumber daya manusia) yang dimiliki rata-rata adalah pustakawan tingkat ahli berpendidikan S1, S2, dan S3. Sehingga jika ditinjau dari kompetensinya dalam memberikan layanan tidak diragukan lagi. Teknologi Informasi yang diaplikasikan sangat mendukung kecepatan dan ketepatan proses layanan seperti program layanan peminjaman, pengembalian buku mandiri, dan tersedianya akses internet gratis. Kedua, hal-hal yang dapat menurunkan derajat kualitas layanan adalah: jumlah koleksi judul buku yang dimiliki perpustakaan baru mencapai 200.000 judul buku dari total buku yang 
harus dimiliki perpustakaan berstandar internasional yaitu sebanyak 4 juta judul buku.

Kondisi Badan Perpustakaan dan Arsip Daerah (BAPUSIPDA) Provinsi Jawa Barat, selain kekurangan buku, perpustakaan bertaraf internasional ini juga masih kekurangan pustakawan, di mana saat ini memiliki 19 pustakawan dari kebutuhan 60 pustakawan. Tidak hanya itu, akses jalan menuju perpustakaan juga belum maksimal (http://www.pikiran-rakyat.com).

Kemudian berdasarkan hasil observasi di lapangan penulis masih menemukan pemustaka yang kurang mendapatkan respon dari pustakawan atau staf perpustakaan BAPUSIPDA. Pernyataan tersebut menjadi hal yang sering terdengar apabila pemustaka menyebarkan informasi kepada teman atau masyarakat sekitar. Padahal hal tersebut dapat memberikan citra negatif terhadap perpustakaan, karena citra terbentuk dari kesan pemustaka terhadap layanan yang diberikan. Selain itu penulis juga menemukan pemustaka yang mengalami kesulitan dalam pencarian koleksi di rak, yang mana hal tersebut terjadi karena apa yang dimuat pada mesin OPAC (Online Public Access Catalog) tidak sesuai dengan keadaan di rak. Kasus ini tentunya sangat disayangkan bila mengingat perpustakaan BAPUSIPDA adalah perpustakaan yang dikatakan sudah bertaraf internasional.

Pengamatan lainnya di BAPUSIPDA Jawa Barat pada tahun 2015, rata-rata pengunjung sebanyak 100-175 per hari. Jumlah ini masih tergolong sedikit bila mengingat bahwa BAPUSIPDA merupakan perpustakaan bertaraf internasional yang mencakup Jawa Barat. Hal ini tentunya menjadi salah satu masalah yang harus segera diselesaikan, dan untuk itu perlu dikaji lebih jauh untuk melihat faktor apa saja yang mungkin mempengaruhinya.

\section{TUJUAN PENELITIAN}

Penelitian ini bertujuan untuk mengetahui hubungan access to information, affect of service, personal control, library as place dengan citra pada perpustakaan BAPUSIPDA Provinsi Jawa Barat. 


\section{KERANGKA PENELITIAN}

\section{Bagan 1.1 Kerangka Penelitian}

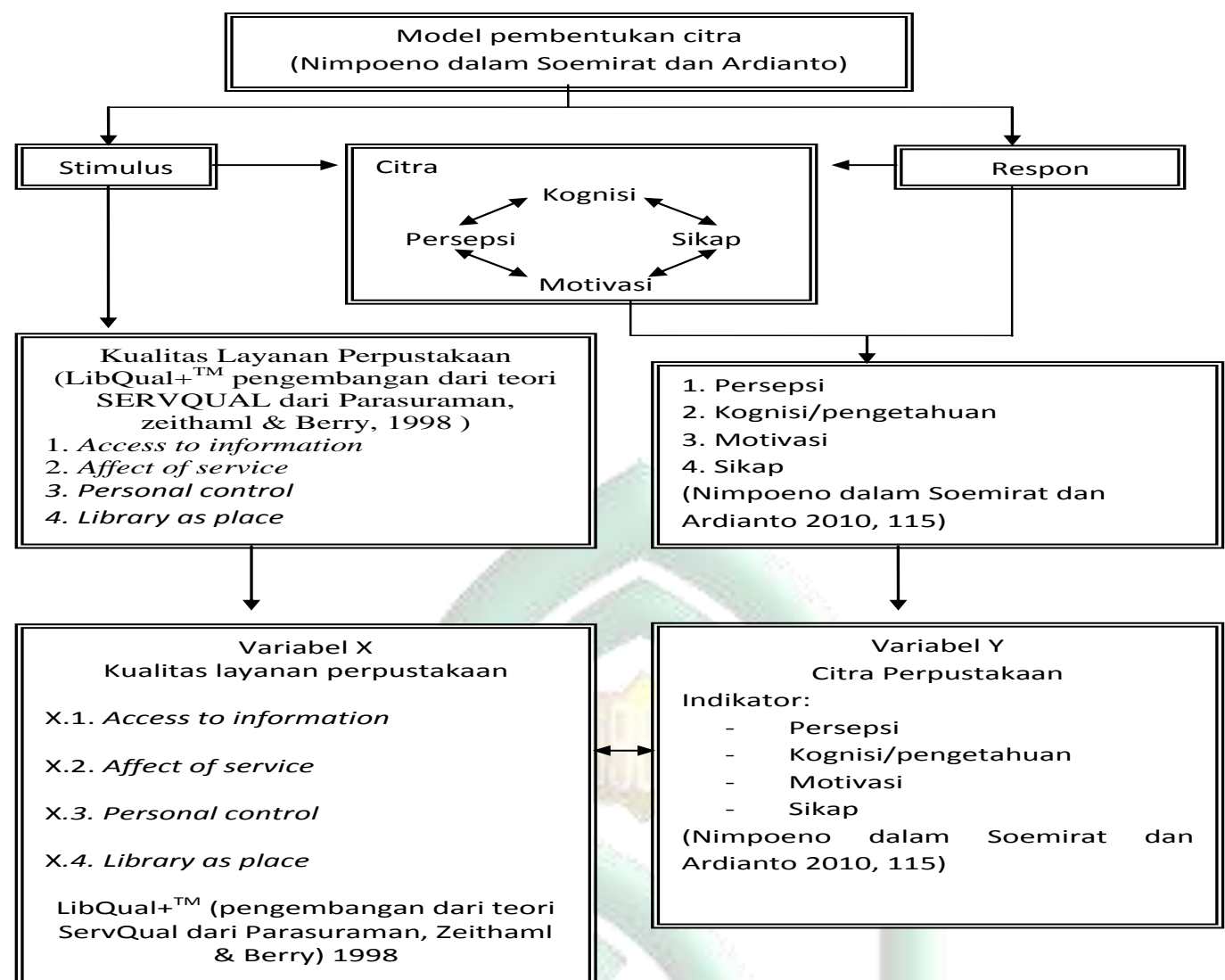

\section{METODOLOGI PENELITIAN}

Metode yang digunakan dalam penelitian ini adalah metode kuantitatif dengan pendekatan survei eksplanatif. Penelitian eksplanatif adalah penelitian yang memberikan penjelasan dan alasan dalam bentuk hubungan sebab akibat (Morissan, 2012: 38). Pertimbangan pemilihan motode survei karena pendekatan ini tidak hanya sekedar menggambarkan terjadinya fenomena tetapi mencoba menjelaskan mengapa fenomena itu terjadi dan apa pengaruhnya. Dengan kata lain, penelitian survei eksplanatif digunakan untuk menjelaskan hubungan antara dua atau lebih variabel. Teknik pengumpulan data melalui penyebaran angket, wawancara, observasi, dan studi pustaka. Analisis data dilakukan dengan terlebih dahulu memproses data yang didapatkan dari angket setelah dimasukkan ke dalam coding sheet. Data diakumulasikan dan disusun serta dianalisis dengan menggunakan teknik analisis deskriptif.

\section{HASIL DAN PEMBAHASAN}

\section{a. Hubungan Access to Information dengan Citra BAPUSIPDA Provinsi Jawa Barat}

Tabel 1. Tabulasi silang access to information $\left(X_{1}\right)$ dengan citra perpustakaan $(\mathrm{Y})$

\begin{tabular}{|c|c|c|c|c|c|c|c|c|c|}
\hline \multirow{3}{*}{\multicolumn{2}{|c|}{$\begin{array}{c}\text { Variabel/Sub } \\
\text { Variabel }\end{array}$}} & \multicolumn{6}{|c|}{ Citra perpustakaan $(\mathrm{Y})$} & \multirow{2}{*}{\multicolumn{2}{|c|}{ Jumlah }} \\
\hline & & \multicolumn{2}{|c|}{ Tinggi } & \multicolumn{2}{|c|}{ Sedang } & \multicolumn{2}{|c|}{ Rendah } & & \\
\hline & & $f$ & $\%$ & $f$ & $\%$ & $\mathrm{f}$ & $\%$ & $f$ & $\%$ \\
\hline \multirow{3}{*}{$\begin{array}{l}\text { Access to } \\
\text { Informati } \\
\text { on }\left(\mathrm{X}_{1}\right)\end{array}$} & Tinggi & 39 & 44.8 & 0 & 0.0 & 0 & 0.0 & 39 & 44.8 \\
\hline & Sedang & 7 & 8.0 & 40 & 46.0 & 1 & 1.1 & 48 & 55.2 \\
\hline & Rendah & 0 & 0.0 & 0 & 0.0 & 0 & 0.0 & 0 & 0.0 \\
\hline \multicolumn{2}{|c|}{ Jumlah } & 46 & 52.9 & 40 & 46.0 & 1 & 1.1 & 87 & 100.0 \\
\hline
\end{tabular}


Tabel 1 di atas menjelaskan tentang kaitan antara access to information dengan citra perpustakaan, berdasarkan tabel tersebut dapat dijelaskan bahwa dari 87 responden, diperoleh yaitu sebesar 40 responden $(46.0 \%)$ menganggap bahwa access to information cukup berhubungan dalam pembentukan citra perpustakaan. Dalam hal ini dapat dikatakan bahwa kinerja layanan perpustakaan dalam aspek access to information cukup berperan pada pembentukan citra perpustakaan. Jadi dengan menyediakan koleksi yang memadai, koleksi yang up to date, serta sesuai dengan kebutuhan pengguna (relevan) akan menciptakan citra yang positif bagi perpustakaan.

Untuk mengetahui korelasi access to information dengan citra perpustakaan, penulis menggunakan analisis data dengan koefisien korelasi rank Spearman. Kemudian berdasarkan masalah mengenai hubungan access to information (X1) dengan citra perpustakaan (Y) maka dapat dirumuskan hipotesis sebagai berikut:

Hipotesis nol (H0): Tidak terdapat hubungan antara access to information dengan citra perpustakaan BAPUSIPDA Provinsi Jawa Barat

Hipotesis kerja (H1): Terdapat hubungan antara access to information dengan citra perpustakaan BAPUSIPDA Provinsi Jawa Barat

Adapun kriteria pengujian hipotesis di atas adalah sebagai berikut (Sugiyono, 2012: 244):

- Jika $\mid \mathrm{t}$ hitung $\mid \geq \mathrm{ta} / 2, \mathrm{n}-2$, maka $\mathrm{H0}$ ditolak dan $\mathrm{H} 1$ diterima

- Jika ta/2, n-2 < t hitung < t1-a/2,n-2, atau nilai signifikansi $(\mathrm{sig})>,a(0,05)$ maka H0 diterima
Selanjutnya hasil perhitungan diperoleh hasil sebagaimana yang dapat dilihat pada tabel di bawah ini.

Tabel 2. Hubungan access to information dengan citra perpustakaan

\begin{tabular}{|c|c|c|c|c|}
\hline Variabel & $\mathrm{r}_{\mathrm{s}}$ & $\mathrm{t}$ hitung & $\mathrm{t}$ tabel & Keputusan \\
\hline $\begin{array}{c}\text { Access to Information } \\
\left(\mathrm{X}_{1}\right) \text { dengan Citra } \\
\text { Perpustakaan }(\mathrm{Y})\end{array}$ & 0.674 & 8.391 & 1.988 & $\mathrm{H}_{0}$ ditolak \\
\hline
\end{tabular}

Berdasarkan tabel di atas dapat dilihat koefisien korelasi rank Spearman adalah sebesar 0.674. Hasil uji signifikansi diperoleh nilai $\mathrm{t}$ hitung sebesar 8.391 dan nilai $\mathrm{t}$ tabel dengan $\mathrm{a}=5 \%$ dan dk (derajat kebenaran) $=\mathrm{n}-2=85$ adalah sebesar 1.988. Maka dapat dilihat bahwa $t$ hitung (8.391) > t tabel (1.988) sehingga HO ditolak. Dengan demikian dapat disimpulkan bahwa terdapat hubungan yang signifikan antara access to information dengan citra perpustakaan. Koefisien korelasi sebesar 0.674 menunjukkan keeratan hubungan access to information dengan citra perpustakaan BAPUSIPDA Provinsi Jawa Barat merupakan hubungan yang kuat. Hal ini dapat diartikan bahwa access to information kuat hubungannya dengan pembentukan citra pada perpustakaan BAPUSIPDA Provinsi Jawa Barat.

\section{b. Hubungan Affect of Service dengan Citra BAPUSIPDA Provinsi Jawa Barat}

Tabel 3. Tabulasi silang antara affect of service $\left(X_{2}\right)$ dengan citra perpustakaan (Y)

\begin{tabular}{|c|c|c|c|c|c|c|c|c|c|}
\hline \multirow{3}{*}{\multicolumn{2}{|c|}{$\begin{array}{c}\text { Variabel/Sub } \\
\text { Variabel }\end{array}$}} & \multicolumn{6}{|c|}{ Citra perpustakaan $(\mathrm{Y})$} & \multirow{2}{*}{\multicolumn{2}{|c|}{ Jumlah }} \\
\hline & & \multicolumn{2}{|c|}{ Tinggi } & \multicolumn{2}{|c|}{ Sedang } & \multicolumn{2}{|c|}{ Rendah } & & \\
\hline & & $F$ & $\%$ & $f$ & $\%$ & $f$ & $\%$ & 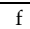 & $\%$ \\
\hline \multirow{3}{*}{$\begin{array}{c}\text { Affect of } \\
\text { Service } \\
\left(\mathrm{X}_{2}\right)\end{array}$} & Tinggi & 44 & 50.6 & 0 & 0.0 & 0 & 0.0 & 44 & 50.6 \\
\hline & Sedang & 2 & 2.3 & 38 & 43.7 & 0 & 0.0 & 40 & 46.0 \\
\hline & $\begin{array}{c}\text { Renda } \\
\mathrm{h}\end{array}$ & 0 & 0.0 & 2 & 2.3 & 1 & 1.1 & 3 & 3.4 \\
\hline \multicolumn{2}{|c|}{ Jumlah } & 46 & 52.9 & 40 & 46.0 & 1 & 1.1 & 87 & 100.0 \\
\hline
\end{tabular}


Tabel di atas menjelaskan tentang kaitan antara affect of service dengan citra perpustakaan, berdasarkan tabel tersebut dapat dijelaskan bahwa dari 87 responden didapat yaitu sebesar 44 responden (50.6\%) menganggap bahwa affect of service memiliki hubungan yang erat dalam pembentukan citra perpustakaan. Dalam hal ini dapat dikatakan bahwa kinerja layanan perpustakaan dalam aspek affect of service sangat berperan dalam pembentukan citra perpustakaan. Jadi dengan adanya petugas yang bersikap ramah dan sopan, dapat diandalkan, dan berwawasan, serta dengan memberikan layanan yang cepat akan menciptakan citra yang positif bagi perpustakaan.

Untuk mengetahui korelasi affect of service dengan citra perpustakaan, penulis menggunakan analisis data dengan koefisien korelasi rank Spearman. Kemudian berdasarkan masalah mengenai hubungan affect of service (X2) dengan citra perpustakaan (Y) maka dapat dirumuskan hipotesis sebagai berikut:

Hipotesis nol (H0): Tidak terdapat hubungan antara affect of service dengan citra perpustakaan BAPUSIPDA Provinsi Jawa Barat

Hipotesis kerja (H1): Terdapat hubungan antara affect of service dengan citra perpustakaan BAPUSIPDA Provinsi Jawa Barat

Adapun kriteria pengujian hipotesis di atas adalah sebagai berikut (Sugiyono, 2012: 244).

- $\quad$ Jika $\mid \mathrm{t}$ hitung $\mid \geq \mathrm{ta} / 2, \mathrm{n}-2$, maka H0 ditolak dan $\mathrm{H} 1$ diterima

- Jika ta/2,n-2 < t hitung < t1-a/2,n-2, atau nilai signifikansi $\left(\mathrm{sig}_{,}\right)>$a $(0,05)$ maka $\mathrm{H} 0$ diterima
Selanjutnya hasil perhitungan diperoleh hasil sebagaimana yang dapat dilihat pada tabel 4 di bawah ini.

Tabel 4. Hubungan affect of service dengan citra perpustakaan

\begin{tabular}{|c|c|c|c|c|}
\hline Variabel & $\mathrm{r}_{\mathrm{s}}$ & $\mathrm{t}$ hitung & $\mathrm{t}$ tabel & Keputusan \\
\hline $\begin{array}{c}\text { Affect of Service } \\
\left(\mathrm{X}_{2}\right) \text { dengan Citra } \\
\text { Perpustakaan }(\mathrm{Y})\end{array}$ & 0.620 & 7.283 & 1.988 & $\mathrm{H}_{0}$ ditolak \\
\hline
\end{tabular}

Berdasarkan tabel di atas dapat dilihat koefisien korelasi rank Spearman adalah sebesar 0.620. Hasil uji signifikansi diperoleh nilai $\mathrm{t}$ hitung sebesar 7.283 dan nilai $\mathrm{t}$ tabel dengan $\mathrm{a}=5 \%$ dan $\mathrm{dk}$ (derajat kebenaran) $=n-2=85$ adalah sebesar 1.988. Maka dapat dilihat bahwa $t$ hitung (7.283) $>t$ tabel (1.988) sehingga HO ditolak. Dengan demikian dapat disimpulkan bahwa terdapat hubungan yang signifikan antara affect of service dengan citra perpustakaan. Koefisien korelasi sebesar 0.620 menunjukkan keeratan hubungan affect of service dengan citra perpustakaan BAPUSIPDA Provinsi Jawa Barat merupakan hubungan yang kuat. Hal ini dapat diartikan bahwa affect of service kuat hubungannya dengan pembentukan citra pada perpustakaan BAPUSIPDA Provinsi Jawa Barat.

\section{c. Hubungan Personal Control dengan Citra BAPUSIPDA Provinsi Jawa Barat}

Tabel 5. Tabulasi silang antara Personal Control $\left(\mathrm{X}_{3}\right)$ dengan citra perpustakaan (Y)

\begin{tabular}{|c|c|c|c|c|c|c|c|c|c|}
\hline \multirow{3}{*}{\multicolumn{2}{|c|}{$\begin{array}{c}\text { Variabel/ Sub } \\
\text { Variabel }\end{array}$}} & \multicolumn{6}{|c|}{ Citra perpustakaan $(\mathrm{Y})$} & \multirow{2}{*}{\multicolumn{2}{|c|}{ Jumlah }} \\
\hline & & \multicolumn{2}{|c|}{ Tinggi } & \multicolumn{2}{|c|}{ Sedang } & \multicolumn{2}{|c|}{ Rendah } & & \\
\hline & & $\mathrm{f}$ & $\%$ & f & $\%$ & $\mathrm{f}$ & $\%$ & $\mathrm{f}$ & $\%$ \\
\hline \multirow{3}{*}{$\begin{array}{c}\text { Personal } \\
\text { Control } \\
\left(\mathrm{X}_{3}\right)\end{array}$} & Tinggi & 46 & 52.9 & 16 & 18.4 & 0 & 0.0 & 62 & 71.3 \\
\hline & Sedang & 0 & 0.0 & 24 & 27.6 & 1 & 1.1 & 25 & 28.7 \\
\hline & Rendah & 0 & 0.0 & 0 & 0.0 & 0 & 0.0 & 0 & 0.0 \\
\hline \multicolumn{2}{|c|}{ Jumlah } & 46 & 52.9 & 40 & 46.0 & 1 & 1.1 & 87 & 100.0 \\
\hline
\end{tabular}

Tabel di atas menjelaskan tentang kaitan antara personal control dengan citra perpustakaan, berdasarkan tabel tersebut 
dapat dijelaskan bahwa dari 87 responden didapat yaitu sebesar 46 responden (52.9\%) menganggap bahwa personal control memiliki hubungan yang erat dalam pembentukan citra perpustakaan. Dalam hal ini dapat dikatakan bahwa kinerja layanan perpustakaan dalam aspek personal control sangat berperan dalam pembentukan citra perpustakaan. Jadi dengan menyediakan peralatan modern, katalog, rambu-rambu, dan tatanan koleksi yang dapat memudahkan pemustaka mencari bahan koleksi yang diinginkannya akan menciptakan citra yang positif bagi perpustakaan.

Untuk mengetahui korelasi personal control dengan citra perpustakaan, penulis menggunakan analisis data dengan koefisien korelasi rank Spearman. Kemudian berdasarkan masalah mengenai hubungan personal control (X3) dengan citra perpustakaan (Y) maka dapat dirumuskan hipotesis sebagai berikut:

Hipotesis nol (H0): Tidak terdapat hubungan antara personal control dengan citra perpustakaan BAPUSIPDA Provinsi Jawa Barat

Hipotesis kerja (H1): Terdapat hubungan antara personal control dengan citra perpustakaan BAPUSIPDA Provinsi Jawa Barat

Adapun kriteria pengujian hipotesis di atas adalah sebagai berikut (Sugiyono, 2012: 244).

- Jika $\mid \mathrm{t}$ hitung $\mid \geq \mathrm{ta} / 2, \mathrm{n}-2$, maka $\mathrm{H} 0$ ditolak dan $\mathrm{H} 1$ diterima

- Jika ta/2,n-2 < t hitung < t1-a/2,n-2, atau nilai signifikansi $(\mathrm{sig})>,a(0,05)$ maka H0 diterima
Selanjutnya hasil perhitungan diperoleh hasil sebagaimana yang dapat dilihat pada tabel di bawah ini.

Tabel 6. Hubungan personal control dengan citra perpustakaan

\begin{tabular}{|c|c|c|c|c|}
\hline Variabel & $\mathbf{r}_{\mathbf{s}}$ & $\begin{array}{c}\mathbf{t} \\
\text { hitung }\end{array}$ & $\mathbf{t}$ tabel & Keputusan \\
\hline $\begin{array}{c}\text { Personal Control }\left(\mathrm{X}_{3}\right) \\
\text { dengan Citra } \\
\text { Perpustakaan }(\mathrm{Y})\end{array}$ & 0.445 & 4.706 & 1.988 & $\mathrm{H}_{0}$ ditolak \\
\hline
\end{tabular}

Berdasarkan tabel di atas dapat dilihat koefisien korelasi rank Spearman adalah sebesar 0.445. Hasil uji signifikansi diperoleh nilai $\mathrm{t}$ hitung sebesar 4.706 dan nilai $\mathrm{t}$ tabel dengan $\mathrm{a}=5 \%$ dan dk (derajat kebenaran) $=\mathrm{n}-2=85$ adalah sebesar 1.988. Maka dapat dilihat bahwa $t$ hitung (4.706) $>\mathrm{t}$ tabel (1.988) sehingga HO ditolak. Dengan demikian dapat disimpulkan bahwa terdapat hubungan yang signifikan antara personal control dengan citra perpustakaan. Koefisien korelasi sebesar 0.445 menunjukkan keeratan hubungan personal control dengan citra perpustakaan BAPUSIPDA Provinsi Jawa Barat merupakan hubungan yang sedang. Hal ini dapat diartikan bahwa personal control cukup kuat hubungannya dengan pembentukan citra pada perpustakaan BAPUSIPDA Provinsi Jawa Barat.

d. Hubungan Library As Place dengan Citra BAPUSIPDA Provinsi Jawa Barat

Tabel 7. Tabulasi silang antara library as place (X4) dengan citra perpustakaan $(\mathrm{Y})$

\begin{tabular}{|c|c|c|c|c|c|c|c|c|c|}
\hline \multirow{3}{*}{\multicolumn{2}{|c|}{ Variabel/ Sub Variabel }} & \multicolumn{6}{|c|}{ Citra perpustakaan $(\mathrm{Y})$} & \multirow{2}{*}{\multicolumn{2}{|c|}{ Jumlah }} \\
\hline & & \multicolumn{2}{|c|}{ Tinggi } & \multicolumn{2}{|c|}{ Sedang } & \multicolumn{2}{|c|}{ Rendah } & & \\
\hline & & $\mathrm{f}$ & $\%$ & $\mathrm{f}$ & $\%$ & $\mathrm{f}$ & $\%$ & f & $\%$ \\
\hline \multirow{3}{*}{$\begin{array}{l}\text { Library as } \\
\text { Place }\left(\mathrm{X}_{4}\right)\end{array}$} & Tinggi & 46 & 52.9 & 3 & 3.4 & 0 & 0.0 & 49 & 56.3 \\
\hline & Sedang & 0 & 0.0 & 36 & 41.4 & 0 & 0.0 & 36 & 41.4 \\
\hline & Rendah & 0 & 0.0 & 1 & 1.1 & 1 & 1.1 & 2 & 2.3 \\
\hline \multicolumn{2}{|c|}{ Jumlah } & 46 & 52.9 & 40 & 46.0 & 1 & 1.1 & 87 & 100.0 \\
\hline
\end{tabular}


Tabel di atas menjelaskan tentang kaitan antara library as place dengan citra perpustakaan, berdasarkan tabel tersebut dapat dijelaskan bahwa dari 87 responden didapat yaitu sebesar 46 responden (52.9\%) menganggap bahwa library as place memiliki hubungan yang erat dalam pembentukan citra perpustakaan. Dalam hal ini dapat dikatakan bahwa kinerja layanan perpustakaan dalam aspek library as place sangat berperan dalam pembentukan citra perpustakaan. Jadi dengan menjadikan perpustakaan sebagai tempat yang nyaman, memiliki fasilitas yang memadai, mengundang (strategis) akan menciptakan citra yang positif bagi perpustakaan.

Untuk mengetahui korelasi library as place dengan citra perpustakaan, penulis menggunakan analisis data dengan koefisien korelasi rank -Spearman. Kemudian berdasarkan masalah mengenai hubungan library as place (X4) dengan citra perpustakaan (Y) maka dapat dirumuskan hipotesis sebagai berikut:

Hipotesis nol (H0): Tidak terdapat hubungan antara library as place dengan citra perpustakaan BAPUSIPDA Provinsi Jawa Barat

Hipotesis kerja (H1): Terdapat hubungan antara library as place dengan citra perpustakaan BAPUSIPDA Provinsi Jawa Barat

Adapun kriteria pengujian hipotesis di atas adalah sebagai berikut (Sugiyono, 2012: 244).

- Jika $\mid \mathrm{t}$ hitung $\mid \geq \mathrm{ta} / 2, \mathrm{n}-2$, maka H0 ditolak dan $\mathrm{H} 1$ diterima

- Jika ta/2,n-2 < t hitung < t1-a/2,n-2, atau nilai signifikansi $($ sig, $)>$ a $(0,05)$ maka H0 diterima
Selanjutnya hasil perhitungan diperoleh hasil sebagaimana yang dapat dilihat pada tabel di bawah ini.

Tabel 8. Hubungan library as place dengan citra perpustakaan

\begin{tabular}{|c|c|c|c|c|}
\hline Variabel & $\mathrm{r}_{\mathrm{s}}$ & $\begin{array}{c}\mathrm{t} \\
\text { hitung }\end{array}$ & $\mathrm{t}$ tabel & Keputusan \\
\hline $\begin{array}{c}\text { Library as Place }\left(\mathrm{X}_{4}\right) \\
\text { dengan Citra Perpustakaan } \\
(\mathrm{Y})\end{array}$ & 0.708 & 9.231 & 1.988 & $\mathrm{H}_{0}$ ditolak \\
\hline
\end{tabular}

Berdasarkan tabel di atas dapat dilihat koefisien korelasi rank Spearman adalah sebesar 0.708. Hasil uji signifikansi diperoleh nilai $\mathrm{t}$ hitung sebesar 9.231 dan nilai $\mathrm{t}$ tabel dengan $a=5 \%$ dan dk (derajat kebenaran) $=n-2=85$ adalah sebesar 1.988. Maka dapat dilihat bahwa $t$ hitung (9.231) > t tabel (1.988) sehingga HO ditolak. Dengan demikian dapat disimpulkan bahwa terdapat hubungan yang signifikan antara library as place dengan citra perpustakaan. Koefisien korelasi sebesar 0.708 menunjukkan keeratan hubungan library as place dengan citra perpustakaan BAPUSIPDA Provinsi Jawa Barat merupakan hubungan yang kuat. Hal ini dapat diartikan bahwa library as place kuat hubungannya dengan pembentukan citra pada perpustakaan BAPUSIPDA Provinsi Jawa Barat.

\section{e. Analisis Inferensial Hubungan Kualitas Layanan (X) dengan Citra BAPUSIPDA Jawa Barat}

Untuk mengetahui korelasi kualitas layanan perpustakaan dengan citra perpustakaan, penulis menggunakan analisis data dengan koefisien korelasi rank Spearman. Kemudian berdasarkan masalah mengenai hubungan kualitas layanan $(X)$ perpustakaan dengan citra perpustakaan (Y) maka dapat dirumuskan hipotesis sebagai berikut:

Hipotesis nol (H0): Tidak terdapat hubungan antara kualitas layanan 
perpustakaan dengan citra perpustakaan BAPUSIPDA Provinsi Jawa Barat

Hipotesis kerja (H1): Terdapat hubungan antara kualitas layanan perpustakaan dengan citra perpustakaan BAPUSIPDA Provinsi Jawa Barat

Adapun kriteria pengujian hipotesis di atas adalah sebagai berikut (Sugiyono, 2012: 244).

- $\quad$ jika $\mid \mathrm{t}$ hitung $\mid \geq \mathrm{ta} / 2, \mathrm{n}-2$, maka $\mathrm{HO}$ ditolak dan $\mathrm{H} 1$ diterima

- Jika ta/2,n-2 < t hitung < t1-a/2,n-2, atau nilai signifikansi (sig, $>$ a $(0,05)$ maka H0 diterima

Selanjutnya hasil perhitungan diperoleh hasil sebagaimana yang dapat dilihat pada tabel di bawah ini:

Tabel 9. Hubungan kualitas layanan perpustakaan dengan citra perpustakaan

\begin{tabular}{|c|c|c|c|c|}
\hline Variabel & $r_{s}$ & $\mathrm{t}$ hitung & $\mathrm{t}$ tabel & Keputusan \\
\hline $\begin{array}{c}\text { Kualitas Layanan } \\
\text { Perpustakaan (X) dengan } \\
\text { Citra Perpustakaan (Y) }\end{array}$ & 0.721 & 9.592 & 1.988 & $\mathrm{H}_{0}$ ditolak \\
\hline
\end{tabular}

Berdasarkan tabel di atas dapat dilihat koefisien korelasi rank Spearman adalah sebesar 0.721. Hasil uji signifikansi diperoleh nilai $\mathrm{t}$ hitung sebesar 9.592 dan nilai $\mathrm{t}$ tabel dengan $\mathrm{a}=5 \%$ dan $\mathrm{dk}$ (derajat kebenaran) $=\mathrm{n}-2=85$ adalah sebesar 1.988. Maka dapat dilihat bahwa t hitung (9.592) > t tabel (1.988) sehingga HO ditolak. Dengan demikian dapat disimpulkan bahwa terdapat hubungan yang signifikan antara kualitas layanan perpustakaan dengan citra perpustakaan. Koefisien korelasi sebesar 0.721 menunjukkan ada hubungan yang kuat antara kualitas layanan perpustakaan dengan citra perpustakaan BAPUSIPDA Provinsi Jawa Barat.

\section{KESIMPULAN}

Berdasarkan hasil analisis data, maka dapat disimpulkan bahwa terdapat hubungan positif yang signifikan antara kualitas layanan perpustakaan dengan citra BAPUSIPDA Provinsi Jawa Barat, dengan koefisien korelasi (0.721). Hal ini menunjukkan bahwa hubungan kualitas layanan perpustakaan dengan citra BAPUSIPDA Provinsi Jawa Barat ada pada taraf yang kuat. Selain itu, hasil tersebut menujukan arah yang positif artinya semakin baik kualitas layanan perpustakaan maka semakin baik pula citra perpustakaan BAPUSIPDA Provinsi Jawa Barat.

\section{DAFTAR PUSTAKA}

Azwar, S. (2004). Reliabilitas dan Validitas. Yogyakarta: Pustaka Pelajar.

Azwar, S. (1997). Sikap Manusia. Yogyakarta: Pustaka Pelajar.

Arikunto, S. (1993). Prosedur Penelitian Suatu Pendekatan Praktek. Jakarta: PT Rineka Cipta.

Bavakutty, M., dan Abdul Majeed, K. C. (2005). Methos For Measuring Quality Of Libraries. New Delhi: Ess Ess Publications.

Bungin, B. (2009). Metodologi Penelitian Kuantitatif. Jakarta: Kencana.

Darmono. (2001). Manajemen dan Tata Kerja Perpustakaan Sekolah. Jakarta: Grasindo.

Darmono. (2007). Perpustakaan Sekolah. Jakarta: Grasindo

Hamidi. (2007). Metode Penelitian dan Teori Komunikasi. Malang: Umm Press.

Kaplan, Robert M. (2012). Pengukuran Psikologi. Jakarta: Salemba Humanika.

Kriyantono, Rachmat. (2009). Teknik Praktis Riset Komunikasi. Jakarta: Kencana. 
Lasa H.S. (2005). Manajemen Perpustakaan. Yogyakarta: Gama Media.

Morrisan, M.A. (2012). Metode Penelitian Survei. Jakarta: Kencana.

Nasution, M.N. (2004). Manajemen jasa Terpadu (Total Service Management). Jakarta: Ghalia Indonesia.

Nurhadi, Muljani A. (2003). Sejarah Perpustakaan dan Perkembangannya di Indonesia. Yogyakarta: Andi.

Rahayuningsih, F. (2007). Pengelolaan Perpustakaan. Yogyakarta: Graha Ilmu.

Rakhmat, Jalaludin. (2011). Psikologi Komunikasi. Bandung: Remaja Rosdakarya.

Shadily, Hassan. (1980). Ensiklopedi Indonesia. Jakarta: Ichtiar.

Siegel, Sidney. (1986). Statistik Nonparametrik Untuk Ilmu-ilmu Sosial. Jakarta: PT. Gramedia.

Soemirat, Soleh dan Elvinaro Ardianto. (2010). Dasar-dasar Public Relations. Bandung: Remaja Rosdakarya.

Sugiyono. (2012). Statistika Untuk Penelitian. Bandung: Alfabeta.

Sugiyono. (2011). Metode Penelitian Kuantitatif, Kualitatif, dan RED. Bandung: Alfabeta.

Sukmadinata, Nana Syaodih. (2009). Metode Penelitian Pendidikan.

Bandung: Rosda.

Sulistyo-Basuki. (2010). Pengantar Ilmu Perpustakaan. Jakarta: Gramedia Pustaka Utama.

Sutarno N.S. (2006). Perpustakaan dan Masyarakat. Jakarta: Sagung Seto.

Uno, H. B. (2009). Teori Motivasi dan Pengukurannya. Jakarta: Bumi Aksara.

Sumber lain:

https://www.libqual.org/ diakses 26 April 2016.

http:/ / kbbi.web.id/ diakses 26 April 2016 http://www.pikiran-

rakyat.com/bandungraya/2012/09/14/203421/perpustak aan-jabar-kekurangan-38-juta-judulbuku diakses 26 April 2016.

Komariah, Neneng dkk.. 2009. Survey Deskriptif Tentang Persepsi Pengguna Terhadap Layanan Gelar Buku Baca Santai. Laporan penelitian Universitas Padjajaran Tersedia pada http://repository.unpad.ac.id/6257 /1/persepsi_pengguna_thdp_ layanan_gelar_buku_bacaan_santai. pdf Diakses 26 April 2016. 